\title{
A PARTICIPAÇÃO POPULAR NA AVALIAÇÃO DE IMPACTO AMBIENTAL: UM OLHAR DEMOCRÁTICO PARA A PROTEÇÃO AMBIENTAL
}

\section{POPULAR PARTICIPATION IN THE ENVIRONMENTAL IMPACT ASSESSMENT: A DEMOCRATIC LOOK AT ENVIRONMENTAL PROTECTION}

\author{
Leandro José Ferreira \\ Escola Superior Dom Helder Câmara - ESDHC - (Belo Horizonte, MG, Brasil) \\ José Cláudio Junqueira Ribeiro \\ Escola Superior Dom Helder Câmara - ESDHC - (Belo Horizonte, MG, Brasil)
}

Recebimento: 21 mar. 2018

Aceitação: 23 maio 2018

\begin{abstract}
Como citar este artigo / How to cite this article (informe a data atual de acesso / inform the current date of access):
FERREIRA, Leandro José; RIBEIRO, José Cláudio Junqueira. A participação popular na avaliação de impacto ambiental: um olhar democrático para a proteção ambiental. Revista da Faculdade de Direito UFPR, Curitiba, PR, Brasil, v. 63, n. 2, p. 59-87, ago. 2018. ISSN 2236-7284. Disponível em: <https://revistas.ufpr.br/direito/article/view/58522>. Acesso em: 30 ago. 2018. DOI: http://dx.doi.org/10.5380/rfdufpr.v63i2.58522.
\end{abstract}

\section{RESUMO}

O presente estudo tem por objetivo analisar a efetiva democracia participativa no âmbito do procedimento de avaliação de impacto ambiental. O princípio da participação popular em matéria ambiental está diametralmente enraizado nos fundamentos do Estado Democrático de Direito. É premissa inafastável no âmbito constitucional que sejam oportunizados à sociedade civil espaços adequados para a eficaz participação popular em matéria ambiental. Para a ocorrência de uma participação efetiva o desenvolvimento do princípio da informação e da educação ambiental é um axioma inarredável. Para tanto foram utilizados, na realização desta pesquisa, o método vertente jurídico-teórico e raciocínio dedutivo com técnica de pesquisa bibliográfica. Ao final da pesquisa, pode-se evidenciar que no Brasil os espaços ofertados para a efetivação do princípio constitucional da participação popular, no que tange ao procedimento de avaliação de impacto ambiental, ainda são limitados no cenário nacional. É preciso o desenvolvimento dos princípios da informação e da educação ambiental para possibilitar uma efetiva participação popular. O direito fundamental ao meio ambiente precisa ser propalado ao máximo e, para tanto, seus atores sociais precisam estar imbuídos de uma participação concreta e efetiva.

\section{PALAVRAS-CHAVE}

Avaliação de impacto ambiental. Democracia participativa. Direito fundamental. Meio ambiente.

\begin{abstract}
The objective of this study is to analyze the effective participatory democracy within the scope of the environmental impact assessment procedure. The principle of popular participation in environmental matters is diametrically rooted in the foundations of the Democratic State of Law. It is an unassailable
\end{abstract}


premise at the constitutional level that civil society should be given suitable spaces for effective public participation in environmental matters. For the occurrence of an effective participation the development of the principle of information and environmental education is an irrefutable axiom. For this purpose, a juridical-theoretical approach and a deductive reasoning with a bibliographic research technique were used in this research. At the end of the research, it can be evidenced that in Brazil the spaces offered for the realization of the constitutional principle of popular participation, regarding the procedure of environmental impact assessment, are still limited in the national scenario. It is necessary to develop the principles of information and environmental education to enable effective participation of the people. The fundamental right to the environment must be promoted to the maximum, and for that, its social actors must be imbued with concrete and effective participation.

\section{KEYWORDS}

Environmental impact assessment. Participative democracy. Fundamental right. Environment.

\section{INTRODUÇÃO}

No primeiro capítulo será realizada uma abordagem no tema da participação popular no Estado Democrático de Direito e suas nuances no cenário nacional.

No segundo capítulo será realizada uma incursão sobre o meio ambiente ecologicamente equilibrado à sadia qualidade de vida e seu status de norma de direito fundamental, bem como será abordado o princípio da democracia participativa como direito-dever de proteção ambiental.

No terceiro capítulo serão traçados os aspectos vigentes do método de avaliação de impacto ambiental e seus desdobramentos conforme a legislação vigente.

No quarto capítulo será realizada uma investigação sobre os momentos em que é oportunizada a participação popular no processo de avaliação de impacto ambiental. Nessa mesma linha será tecida uma análise crítica sobre esses limitados espaços de participação popular.

No quinto capítulo será evidenciado que um novo paradigma de participação popular na avaliação de impacto ambiental precisa ser pensado e desenvolvido, de modo a permear a participação da coletividade durante todo o processo de avaliação de impacto ambiental, desde a etapa da proposta até a fase do acompanhamento.

Para esse fim, os princípios da informação e da educação ambiental serão devidamente apresentados, ao passo que são pilares de sustentação do princípio da participação popular em matéria ambiental, pois não se participa daquilo que não se conhece e que não se entende.

Será apresentado, com o propósito de apontar alternativas ao melhoramento do modelo brasileiro, um modelo semelhante de participação popular em todas as etapas da Avaliação de Impacto Ambiental (AIA), adotado na bacia do rio Arkansas (Estados Unidos da América), que representou grande avanço na promoção da participação popular em matéria de meio ambiente. 
Para tanto, foram utilizados na realização deste ensaio o levantamento de conteúdos doutrinários, numa técnica dedutiva em método teórico-documental, com ênfase na pesquisa exploratória, adotando como marco teórico os estudos sobre democracia participativa em Paulo Bonavides (2003), participação popular na tomada de decisões ambientais em Mirra (2011) e participação comunitária em todas as fases da AIA em Fonseca (2015), em que se apontam como alternativa os estudos discutidos por Thomé e Ribeiro (2016) e também por Canter (1977) no que tange ao modelo adotado na bacia do rio Arkansas.

A pesquisa se justifica na medida em que um novo modelo de avaliação de impacto ambiental, que aproxime a população da verdadeira discussão ambiental, precisa ser pensado. O bem ambiental pertence a toda a coletividade, portanto, esta tem o direito-dever de se manifestar diante daqueles projetos que possam causar significativo impacto ambiental. A discussão vai além, pois o enfrentamento da questão se faz necessário na medida em que a sociedade anseia por uma adequada promoção e proteção do direito fundamental ao meio ambiente equilibrado à sadia qualidade de vida, mediante decisões justas e democráticas que primem pela verdadeira concretização dessa proteção.

\section{A PARTICIPAÇÃO POPULAR NO ESTADO DEMOCRÁTICO DE DIREITO}

O princípio da participação popular está consubstanciado por todo o texto constitucional, no qual se estabelece e se fixa como uma das colunas mestras da fundação do Estado Democrático de Direito, quando especificamente no art. 1º, parágrafo único, da Constituição Federal de 1988, evidencia-se que: “Todo o poder emana do povo, que o exerce por meio de representantes eleitos ou diretamente, nos termos desta Constituição” (BRASIL, 1988).

Não existe, no Estado Democrático de Direito, decisão que importe à sociedade que não seja objeto de sua própria apreciação, haja vista que a concretização dos direitos fundamentais passa diametralmente pelos preceitos da democracia participativa. Conforme salienta Bonavides, "Nisso reside a essência desse figurino de constitucionalidade que há de ser o mais democrático, o mais aberto, o mais legítimo dos modelos de organização da democracia emancipatória do futuro nos países periféricos” (BONAVIDES, 2003, p. 25).

A democracia participativa, conforme evidenciado no Estado democrático brasileiro, normatizado pela consagração do direito fundamental à participação, promove o contento da população aos níveis de tomada de decisões. No Estado Democrático de Direito todo poder emana do povo, conforme corrobora a doutrina: "Isso porque, no moderno estágio de evolução da doutrina, 
todo poder é uno no Estado e emana do povo, sendo apenas distribuídas as funções pelos diversos órgãos do Executivo, do Legislativo e do Judiciário” (ZANETI JR., 2013, p. 48).

Cumpre destacar que o direito fundamental à participação não está ligado somente àquela democracia-representativa que é efetivada por meio do sufrágio universal. Ao contrário, o avanço epistemológico da matéria evidencia uma real participação denominada de democracia participativa, corroborando a necessidade de aproximação da sociedade civil com aquelas decisões políticas que lhe são inerentes. O ponto de partida da evolução da democracia participativa está diretamente ligado ao avanço dos direitos fundamentais em suas dimensões variadas, conforme salienta Bulos: “Os direitos fundamentais de sexta geração correspondem à democracia, à liberdade de informação e ao pluralismo. A democracia é um direito fundamental, porque o arbítrio não se irmana com o regime das liberdades públicas, que se opõe à força, à brutalidade, ao abuso de poder” (BULOS, 2017, p. 531-532).

A elevação do direito à participação popular ao nível de direito fundamental de sexta geração representa a importância constitucional que é acertadamente destinada à norma, pois é por meio dela que a população poderá exercer a sua manifestação concreta de poder conforme a Constituição. Assim, Paulo Bonavides aponta que “A democracia participativa é um direito constitucional progressivo e vanguardeiro. É direito que veio para repolitizar a legitimidade e reconduzi-la às suas nascentes históricas, ou seja, àquele período em que foi bandeira de liberdade dos povos” (BONAVIDES, 2003, p. 33).

Cristalino, portanto, o direito à participação popular, por meio da democracia participativa, que emana da Constituição Federal norma que permite o acesso da sociedade civil à tomada de decisões nas esferas de poder, prestigiando a manifestação volitiva da vontade social por meio de uma afirmação positiva de atuação nos meandros da governança pública. Doutrina abalizada sobre o tema aponta:

O princípio democrático, no âmbito do constitucionalismo contemporâneo (e o brasileiro não foge à regra), assume a condição de princípio estruturante e indissociável da moderna noção de Estado Constitucional, este compreendido como um Estado Democrático de Direito, tal como solenemente enunciado no art. $1^{\circ}$ da Constituição Federal de 1988 (doravante apenas CF/88). (SARLET; FENSTERSEIFER, 2015, p. 710).

Portanto, resta concreto o direito fundamental à participação popular que deve ser objetivado pelo Poder Público a fim de legitimar sua atuação e suas escolhas ante as posições e manifestações da população, pois, no Estado Democrático de Direito, todo o poder emana do povo. Para fins didáticos, no que tange ao objetivo proposto no presente estudo, uma abordagem específica da participação popular no que tange à matéria ambiental se faz necessária, conforme se verá a seguir. 


\title{
2 O DIREITO FUNDAMENTAL AO MEIO AMBIENTE EQUILIBRADO À SADIA QUALIDADE DE VIDA E À DEMOCRACIA PARTICIPATIVA
}

Dois temas conexos e duas espécies de direitos fundamentais que norteiam o Estado Democrático de Direito. Essa é uma forma simples de definir dois temas inerentes à pessoa humana que foram contemplados na Constituição Federal de 1988 a um só tempo e em um só espaço. O art. 225 da CF/88 inaugurou norma expressa de proteção ambiental e ao mesmo tempo vinculou essa proteção à efetiva participação popular: “Todos têm direito ao meio ambiente ecologicamente equilibrado, bem de uso comum do povo e essencial à sadia qualidade de vida, impondo-se ao Poder Público e à coletividade o dever de defendê-lo e preservá-lo para as presentes e futuras gerações” (BRASIL, 1988).

O direito fundamental ao meio ambiente equilibrado se vincula diretamente à dignidade da pessoa humana pelo fato de abrigar a própria vida. Meio ambiente sadio e equilibrado, direito à vida e dignidade da pessoa humana são direitos fundamentais agregados e indissociáveis em todas as suas formas. Conforme ensinam Leandro José Ferreira e Magno Federici Gomes:

\begin{abstract}
A doutrina passa a evidenciar não apenas a elevação do meio ambiente ao status de norma constitucional, mas passa também a considerá-lo como norma constitucional de direito fundamental, o que por certo não poderia ser evidenciado de outra forma, pois o meio ambiente devidamente equilibrado é responsável por reger a vida em todas as suas formas (FERREIRA; GOMES, 2017, p. 628).
\end{abstract}

No que tange à democracia participativa, é imperioso ressaltar que a doutrina congrega seu alicerce no princípio da dignidade da pessoa, em que o ato de participar está diametralmente conexo ao núcleo da dignidade da pessoa humana, conforme se depreende da seguinte passagem doutrinária:

A democracia, por sua vez, guarda relação com a própria dignidade da pessoa humana e os direitos humanos e fundamentais que lhe são correlatos, pois, a exemplo do que bem leciona Peter Haberle, a democracia é a garantia organizacional e política da dignidade humana e do pluralismo, ao passo que essa (a dignidade humana) assume a condição de premissa e verdadeiro pressuposto antropológico do Estado Democrático (e socioambiental, há de acrescer!) de Direito (SARLET; FENSTERSEIFER, 2015, p. 710).

Portanto, a concepção em adotar o direito fundamental ao meio ambiente e o direito fundamental à democracia participativa como inerentes a dignidade da pessoa humana se mostra verdadeiramente real.

Foi instituído, portanto, que o direito fundamental ao meio ambiente ecologicamente equilibrado à sadia qualidade de vida deve ser protegido e preservado pelo Poder Público e também pela coletividade. De forma acertada o legislador constituinte reconheceu a importância do meio ambiente saudável e ecologicamente equilibrado para o abrigo e o desenvolvimento da vida humana. 
Mas do que isso, acertou o constituinte ao vincular a proteção e preservação ambiental ao crivo, também, da coletividade, pois o meio ambiente é inerente a toda vida humana planetária e, por isso, todos têm o dever de preservar. Nesse sentido, ensinam Eduardo Fortunato Bim e Talden Farias que “Poucos interesses podem ser tão gerais quanto o do meio ambiente ecologicamente equilibrado, tendo em vista o seu caráter difuso e a sua indispensabilidade à manutenção da vida e da qualidade de vida” (BIM; FARIAS, 2015, p. 207).

À coletividade foi atribuído o dever de preservar e de proteger o meio ambiente. Mas também foram atribuídos o dever e o direito da participação democrática para a promoção da defesa do meio ambiente ecologicamente equilibrado à sadia qualidade de vida. Conforme preceitua a doutrina, “A área ambiental, conforme se tem entendido, foi pioneira na incorporação da participação popular como elemento indissociável das estratégias a serem adotadas para a proteção do meio ambiente” (MIRRA, 2011, p. 52).

A própria natureza de direito fundamental do meio ambiente equilibrado à sadia qualidade de vida permite e assegura o ideal da participação social, pois quanto mais atores envolvidos na causa da proteção ambiental, mais chances a preservação tem de ser efetivada. Na verdade, o Brasil, ao caracterizar o meio ambiente como direito fundamental e propiciar a participação popular para sua efetivação, acabou por englobar os avanços da conscientização ambiental no âmbito internacional.

Destaque para a Conferência das Nações Unidas sobre o Meio Ambiente e Desenvolvimento realizada no ano de 1992 na cidade do Rio de Janeiro, que, entre outras coisas, viabilizou a junção dos temas meio ambiente, informação e participação cidadã. Conforme preceitua Mirra: “Digna de nota, na matéria, é a concepção adotada pela Declaração do Rio de 1992 de relacionar, estritamente, participação popular, informação e acesso à justiça em tema ambiental” (MIRRA, 2011, p. 59).

Nesse passo, importante apresentar o Princípio 10 da Declaração do Rio no ano de 1992:

\begin{abstract}
A melhor maneira de tratar as questões ambientais é assegurar a participação, no nível apropriado, de todos os cidadãos interessados. No nível nacional, cada indivíduo terá acesso adequado às informações relativas ao meio ambiente de que disponham as autoridades públicas, inclusive informações acerca de materiais e atividades perigosas em suas comunidades, bem como a oportunidade de participar dos processos decisórios. Os Estados irão facilitar e estimular a conscientização e a participação popular, colocando as informações à disposição de todos. Será proporcionado o acesso efetivo a mecanismos judiciais e administrativos, inclusive no que se refere à compensação e reparação de danos (CONFERÊNCIA DAS NAÇÕES UNIDAS SOBRE MEIO AMBIENTE E DESENVOLVIMENTO, 1992).
\end{abstract}

Em linhas gerais, o Princípio $\mathrm{n}^{\circ} 10$ da Declaração do Rio 92 tratou de evidenciar a necessidade da participação popular nos processos decisórios nos níveis internacional, nacional e 
regional, além de prestigiar o acesso à informação em todos os âmbitos e níveis, incumbindo ao Poder Público facilitar e estimular a conscientização de toda a coletividade.

Merece destaque ainda a Convenção sobre o Acesso à Informação, a Participação do Público no Processo Decisório e o Acesso à Justiça em Matéria de Meio Ambiente, conhecida como Convenção de Aarhus de 25/06/1998, que entrou em vigor em 30/10/2001. A Convenção de Aarhus foi concebida pelo Comitê de Políticas de Meio Ambiente, integrante da Comissão Econômica para a Europa (ONU) na cidade de Aarhus, na Dinamarca (MACHADO, 2018).

A Convenção destaca-se ao evidenciar a necessidade de ampliação da informação e da participação nos processos decisórios ambientais, portanto, é possível afirmar que não se trata de mais uma convenção de direito ambiental, ao contrário, a afirmação deve ser mais profunda, no sentido de admitir que se trata de uma convenção preocupada em introduzir a democracia participativa nas questões e nas demandas ambientais.

Assim, Izabel Cristina da Silva Sampaio revela que

Não há dúvida de que esta Convenção avançou significativamente no reconhecimento e proteção dos direitos de acesso à informação, participação do público e acesso à justiça. A importância do papel desempenhado por esses três direitos pode ser verificada na menção que lhes foi feita nos objetivos da Convenção (SAMPAIO, 2013, p. 14.247).

Na esfera do Direito Internacional Regional, merece destaque a Convenção de Escazú, Costa Rica. Trata-se do Acordo Regional sobre Acesso à Informação, Participação e Justiça em Matérias Ambientais na América Latina e no Caribe. Essa Convenção demonstra claramente que a América Latina e o Caribe avançam no sentido de promover instrumento internacional destinado a evidenciar a importância da informação e da participação em matérias ambientais. O art. $1 .^{\circ}$ da Convenção de Escazú aponta qual o seu objetivo central:

O objetivo deste acordo é garantir a implementação eficaz na América Latina e no Caribe dos direitos de acesso à informação ambiental, participação do público no processos de tomada de decisão ambiental e acesso à justiça em questões ambientais, bem como a criação e fortalecimento de capacidades e cooperação, contribuindo para a proteção do direito de cada pessoa, do presente e do futuro, de viver em um ambiente saudável e desenvolvimento sustentável. (ORGANIZAÇÃO DAS NAÇÕES UNIDAS, 2018, tradução nossa) ${ }^{1}$.

A Convenção de Escazú conta com 26 artigos e anuência de 33 países da América Latina e do Caribe, sendo que o Brasil é parte integrante deste acordo regional que visa propagar o princípio

\footnotetext{
1 "El objetivo del presente Acuerdo es garantizar la implementación plena y efectiva en América Latina y el Caribe de los derechos de acceso a la información ambiental, participación pública en los procesos de toma de decisiones ambientales y acceso a la justicia en asuntos ambientales, así como la creación y el fortalecimiento de las capacidades y la cooperación, contribuyendo a la protección del derecho de cada persona, de las generaciones presentes y futuras, a vivir en un medio ambiente sano y al desarrollo sostenible.”
} 
da informação ambiental, da participação pública na tomada de decisões ambientais e acesso à justiça ambiental. Trata-se de importante instrumento de âmbito regional que, em grande parte, se condensa a partir do Princípio n ${ }^{\circ} 10$ da Declaração do Rio 92 e da Convenção de Aarhus.

Nada mais evidente, portanto, admitir que o princípio da informação ambiental e o princípio da participação popular na tomada de decisões ambientais estão na ordem do dia, tanto no cenário internacional, quanto no regional e também no nacional, de modo que qualquer processo ou procedimento ambiental que não venha a admitir a completa aplicação desses princípios estará certamente fadado ao fracasso.

Ingo Wolfgang Sarlet e Tiago Fensterseifer apontam que “[...] é possível identificar os três elementos-chave ou pilares que alicerçam o conceito de participação pública em matéria ambiental: (a) participação pública na tomada de decisões; (b) acesso à informação; (c) acesso à Justiça” (SARLET; FENSTERSEIFER, 2015, p. 719).

Frise-se nesse sentido que

[...] Todo esse movimento culminou com uma intensa participação popular no processo constituinte, a partir da formação da Frente Nacional de Ação Ecológica na Constituinte, que findou por contribuir, decisivamente, para a inserção de todo um capítulo referente ao meio ambiente na Constituição Federal de 1988 (MIRRA, 2011, p. 68).

A bem da verdade, a participação popular em matéria ambiental não se restringe à mera liberalidade de uma eventual participação por parte da comunidade, pois a norma constitucional determina um direito-dever de participação na tomada de decisões. Romeu Thomé e José Cláudio Junqueira Ribeiro destacam que

No Estado Democrático e Socioambiental de Direito, os cidadãos têm o direito (e o dever)
de participar de decisões que possam vir a afetar o equilíbrio ambiental. Há inúmeros
mecanismos para proteção do meio ambiente que possibilitam a efetiva aplicação do
princípio democrático (ou da participação comunitária) (THOMÉ; RIBEIRO, 2016, p. 73,
tradução nossa) ${ }^{2}$.

Portanto, é possível considerar, para fins do tema proposto no presente estudo, que a participação popular em matéria ambiental se constitui em um direito-dever, e é premissa inarredável no Estado Democrático de Direito que deva ser adequadamente oportunizada pelo Poder Público, como fim da promoção do direito fundamental ao meio ambiente equilibrado e do princípio da democracia participativa.

\footnotetext{
2 "In the Democratic and Social Environmental Rule of Law, citizens have the right (and the obligation) to take part in decisions that may affect environmental balance. There are several mechanisms to protect the environment that allow for the effective application of the democratic principle (or the democratic participation).”
} 


\section{ASPECTOS DO MÉTODO DE AVALIAÇÃO DE IMPACTO AMBIENTAL}

A origem do método de Avaliação de Impacto Ambiental tem início nos anos de 1960 nos Estados Unidos, diante da necessidade à época por uma maior certeza técnica quanto à previsão de impactos ambientais de empreendimentos industriais. Alberto Fonseca leciona que: “A literatura global é quase unânime em apontar a publicação, em 1969, do National Environmental Policy Act (NEPA) nos Estados Unidos como o primeiro exemplo de legislação mundial que tornou obrigatória a avaliação de impacto ambiental por agentes governamentais” (FONSECA, 2015, p. 28).

Externando concordância quanto à origem do método de Avaliação de Impacto Ambiental no cenário internacional, Amado aponta que "O nascimento do AIA se operou nos EUA em 1969, com a aprovação pelo Congresso americano da Lei da Política Nacional do Meio Ambiente daquela nação, com vigência a partir de $1^{\circ}$ de janeiro de 1970” (AMADO, 2016, p. 186).

Para fins didáticos, naquilo que interessa ao tema proposto para discussão, adotar-se-á o conceito segundo o qual Avaliação de Impacto Ambiental é um gênero, do qual o Estudo de Impacto Ambiental (EIA) é uma espécie, seguindo aqui os apontamentos de Luis Enrique Sánchez (2008), adotados por Alberto Fonseca (2015) e Frederico Amado (2016). Na mesma linha, Silva leciona que

O Estudo Prévio de Impacto Ambiental é uma modalidade de Avaliação de Impacto Ambiental (AIA) e deve ser realizado para subsidiar o procedimento de licenciamento ambiental de atividades consideradas efetiva ou potencialmente causadoras de significativa degradação do meio ambiente (SILVA, 2012, p. 204).

Destaca-se que o Relatório de Impacto Ambiental (RIMA) se trata de um relatório resumido e adequado à compreensão pública do EIA: “[T]em sido os estudos de avaliação de impacto, como, por exemplo, o Estudo de Impacto Ambiental (EIA) e sua síntese amigável, o Relatório de Impacto Ambiental (RIMA)” (FONSECA, 2015, p. 27).

Por meio deste pensamento é possível conceber um conceito para a AIA: “[...] pode-se definir processo de avaliação de impacto ambiental como um conjunto de procedimentos concatenados de maneira lógica, com a finalidade de analisar a viabilidade ambiental de projetos, planos e programas, e fundamentar uma decisão a respeito” (SÁNCHEZ, 2008, p. 92).

Nesse mesmo sentido, continua Sánchez a detalhar qual a finalidade da avaliação de impacto ambiental, em que demonstra claramente o caráter genérico da AIA e o caráter específico do EIA. Atente-se para as finalidades:

A finalidade da avaliação de impacto ambiental é considerar os impactos ambientais antes de se tomar qualquer decisão que possa acarretar significativa degradação da qualidade do meio ambiente. Para cumprir esse papel, a AIA é organizada de forma a que seja realizada uma série de atividades seqüenciais, concatenadas de maneira lógica. A esse conjunto de 
atividades e procedimentos se dá o nome de processo de avaliação de impacto ambiental. Em geral, esse processo é objeto de regulamentação, que define detalhadamente os procedimentos a serem seguidos, de acordo com os tipos de atividades sujeitos à elaboração prévia de um estudo de impacto ambiental, o conteúdo mínimo desse estudo e as modalidades de consulta pública, entre outros assuntos (SÁNCHEZ, 2008, p. 92).

Evidencia-se que, no Brasil, o primeiro instrumento legal a tratar da Avaliação de Impacto Ambiental foi a Lei 6.938/81, ao estabelecer os instrumentos da Política Nacional do Ambiente. O art. 9 , inciso III, da Lei 6.938/81, assinala que "São instrumentos da Política Nacional do Meio Ambiente: [...] III - a avaliação de impactos ambientais [...]” (BRASIL, 1981, grifo nosso).

Com a Lei 6.938/81 a Avaliação de Impacto Ambiental se torna instrumento da Política Pública Nacional do Meio Ambiente, importando em instrumento adequado à preservação e conservação do meio ambiente ecologicamente equilibrado à sadia qualidade de vida. Após, entrou em cena a Resolução Conama 01/86, que tratou de disciplinar alguns aspectos da AIA. Nas palavras de Alberto Fonseca, “O grande marco, porém, da regulação da AIA no Brasil se deu em 1986, quando o CONAMA publicou a resolução 01/86, disciplinando diversos aspectos de conteúdo e de procedimento da AIA no Brasil” (FONSECA, 2015, p. 29). O art. $1^{\circ}$ da Resolução Conama 01/86 tratou de considerar, como impacto ambiental, aquelas alterações no meio ambiente causadas pela atividade humana: “Artigo $1^{\circ}$ - Para efeito desta Resolução, considera-se impacto ambiental qualquer alteração das propriedades físicas, químicas e biológicas do meio ambiente, causada por qualquer forma de matéria ou energia resultante das atividades humanas que, direta ou indiretamente [...]” (BRASIL, 1986).

$\mathrm{O}$ art. $2^{\circ}$ da Resolução Conama 01/86 condicionou o licenciamento ambiental de algumas atividades potencialmente modificadoras do meio ambiente à elaboração de Estudo de Impacto Ambiental. Em sequência, com a constitucionalização do direito ambiental consubstanciado no art. 225 da CF/88, confirmou a assertiva de que aquelas atividades potencialmente modificadoras do meio ambiente estão sujeitas ao estudo prévio de impacto ambiental.

Nessa mesma linha, ensina Eduardo Fortunato Bim que “[...] a proteção ao meio ambiente (CF, art. 225) materializa-se de diversas formas, sendo uma delas através do estudo prévio de Impacto Ambiental, 'na forma da lei' para a instalação de obra ou atividade potencialmente causadora de significativa degradação do meio ambiente” (BIM, 2015, p. 165).

Ponto que levanta discussões na doutrina é exatamente saber o sentido da expressão “significativa degradação ambiental”, haja vista que o critério é bastante subjetivo e deixa o sentido da norma aberto a possíveis interpretações: "No tocante à definição de significativa degradação ambiental, percebe-se que não há um conceito legal, podendo sim dizer que se situa na esfera do 
indeterminado. O termo ‘significativo’ é de grande subjetividade” (GOMES; TEIXEIRA, 2017, p. 139).

A Resolução Conama 01/86 aponta em seu art. $2^{\circ}$ uma lista, exemplificativa, daquelas atividades com potencial de significativa degradação ambiental:

Artigo $2^{\circ}$ - Dependerá de elaboração de estudo de impacto ambiental e respectivo relatório de impacto ambiental - RIMA, a serem submetidos à aprovação do órgão estadual competente, e do IBAMA e1n caráter supletivo, o licenciamento de atividades modificadoras do meio ambiente, tais como:

I - Estradas de rodagem com duas ou mais faixas de rolamento;

II - Ferrovias;

III - Portos e terminais de minério, petróleo e produtos químicos;

IV - Aeroportos, conforme definidos pelo inciso 1, artigo 48, do Decreto-Lei ${ }^{\circ}$ 32, de 18.11.66;

V - Oleodutos, gasodutos, minerodutos, troncos coletores e emissários de esgotos sanitários; VI - Linhas de transmissão de energia elétrica, acima de 230KV;

VII - Obras hidráulicas para exploração de recursos hídricos, tais como: barragem para fins hidrelétricos, acima de 10MW, de saneamento ou de irrigação, abertura de canais para navegação, drenagem e irrigação, retificação de cursos d’água, abertura de barras e embocaduras, transposição de bacias, diques;

VIII - Extração de combustível fóssil (petróleo, xisto, carvão);

IX - Extração de minério, inclusive os da classe II, definidas no Código de Mineração;

$\mathrm{X}$ - Aterros sanitários, processamento e destino final de resíduos tóxicos ou perigosos;

Xl - Usinas de geração de eletricidade, qualquer que seja a fonte de energia primária, acima de $10 \mathrm{MW}$;

XII - Complexo e unidades industriais e agro-industriais (petroquímicos, siderúrgicos, cloroquímicos, destilarias de álcool, hulha, extração e cultivo de recursos hídricos);

XIII - Distritos industriais e zonas estritamente industriais - ZEI;

XIV - Exploração econômica de madeira ou de lenha, em áreas acima de 100 hectares ou menores, quando atingir áreas significativas em termos percentuais ou de importância do ponto de vista ambiental;

XV - Projetos urbanísticos, acima de 100ha. ou em áreas consideradas de relevante interesse ambiental a critério da SEMA e dos órgãos municipais e estaduais competentes;

XVI - Qualquer atividade que utilize carvão vegetal, em quantidade superior a dez toneladas por dia. (BRASIL, 1986).

Como dito alhures, trata-se de rol exemplificativo, pois o órgão ambiental licenciador poderá verificar a necessidade de estudo prévio de impacto ambiental para a liberação de determinada atividade, ainda que ela não esteja na lista da Resolução Conama 01/86.

Resumidamente, é importante destacar as etapas do processo da Avaliação de Impacto Ambiental com o intuito de objetivar melhores condições de entendimento sobre o capítulo que será proposto em sequência. Para Alberto Fonseca, o processo de AIA constitui-se de sete etapas sequenciais; vejamos: “[...] o processo de AIA pode ser resumido, conforme mostra a Figura 1, em sete etapas sequenciais: 1) proposta, 2) triagem, 3) escopo, 4) estudos, 5) análise, 6) decisão e 7) acompanhamento” (FONSECA, 2015, p. 30). 
Tendo, de forma sucinta, apresentado alguns aspectos relacionados ao processo de avaliação de impacto ambiental, passaremos à análise daqueles momentos que são oportunizados pela legislação para a manifestação popular.

Todavia, cabe observar, conforme previsto no Art. $6^{\circ}$, inciso II, da Resolução Conama 01/86, há que se proceder, para a elaboração do EIA, à análise dos prováveis impactos ambientais, identificando-os e quantificando-os quanto à sua magnitude. Para essa análise de predição foram desenvolvidas metodologias denominadas genericamente de métodos de avaliação de impactos ambientais, a exemplo da matriz de Leopold.

\section{ANÁLISE CRÍTICA DOS ESPAÇOS OPORTUNIZADOS PARA PARTICIPAÇÃO POPULAR NA AVALIAÇÃO DE IMPACTO AMBIENTAL}

Conforme demonstrado alhures, o instrumento de avaliação de impacto ambiental constituise em instrumento da Política Nacional do Meio Ambiente e se mostra como um importante mecanismo de conservação e proteção ambiental, pois determina a confecção de estudos ambientais adequados para o licenciamento daquelas atividades passíveis de significativa degradação ambiental. Forçoso concluir que se trata de mecanismo adequado à implementação da proteção do direito fundamental ao meio ambiente ecologicamente equilibrado à sadia qualidade de vida.

Quando se fala em proteção e conservação do meio ambiente equilibrado à sadia qualidade de vida, pelo menos uma assertiva deve ser confirmada, qual seja, a de que a proteção do meio ambiente depende dos esforços do Poder Público e também de toda a coletividade que tem o direitodever de ampla participação nas tomadas de decisões. Por isso, deve ser louvado o dispositivo constitucional elencado no art. 225 da CF/88, que ensejou esse direito-dever da participação comunitária.

Contudo, conforme se passará a verificar, no âmbito da Avaliação de Impacto Ambiental essa democracia participativa é bastante limitada, pois a participação popular/comunitária fica autorizada, a critério do órgão licenciador, somente nas audiências púbicas. Esse é o dispositivo contido no art. 11 da Resolução Conama 01/86:

\footnotetext{
Artigo 11 - Respeitado o sigilo industrial, assim solicitando e demonstrando pelo interessado o RIMA será acessível ao público. Suas cópias permanecerão à disposição dos interessados, nos centros de documentação ou bibliotecas da SEMA e do estadual de controle ambiental correspondente, inclusive o período de análise técnica,

$\S 1^{\circ}$ - Os órgãos públicos que manifestarem interesse, ou tiverem relação direta com o projeto, receberão cópia do RIMA, para conhecimento e manifestação,

$\S 2^{\circ}$ - Ao determinar a execução do estudo de impacto ambiental e apresentação do RIMA, o estadual competente ou o IBAMA ou, quando couber o Município, determinará o prazo para
} 
recebimento dos comentários a serem feitos pelos órgãos públicos e demais interessados e, sempre que julgar necessário, promoverá a realização de audiência pública para informação sobre o projeto e seus impactos ambientais e discussão do RIMA (BRASIL, 1986).

Conforme esse preceito normativo, o espaço para a manifestação popular está assegurado mediante a apresentação do RIMA, versão resumida do EIA, ao final da análise dos estudos de impacto, desde que o órgão público julgue necessário a realização de audiência pública, ou por solicitação, conforme previsto no art. $2^{\circ}$ da Resolução Conama 09/87: “Art. $2^{\circ}$ - Sempre que julgar necessário, ou quando for solicitado por entidade civil, pelo Ministério Público, ou por 50 (cinquenta) ou mais cidadãos, o Órgão de Meio Ambiente promoverá a realização de audiência pública” (BRASIL, 1990).

Entretanto, a audiência pública para vista e análise do RIMA continuou sendo o único espaço disponível para a manifestação popular que, convenhamos, é muito limitada. Uma única oportunidade para a participação popular, sem a adequada promoção da correta informação sobre o projeto e sem a adequada educação ambiental, não promove o debate adequado e, por consequência, não implementa o ideal da democracia participativa. Mirra confirma que: “[...] se a possibilidade de intervenção da população for aberta apenas em momento adiantado ou no fim do processo decisório, ou quando a decisão já tiver sido tomada, não se poderá falar em autêntica participação pública ambiental” (MIRRA, 2011, p. 156).

Romeu Thomé e José Cláudio Junqueira Ribeiro consideram a existência de limitação dos espaços oportunizados à concreta participação popular:

O ordenamento jurídico do Brasil, por sua vez, é tímido ao positivar instrumentos de informação e participação relacionados à avaliação de impactos ao meio ambiente. No âmbito de competência federal, a Resolução CONAMA 09/87 determina que o órgão ambiental licenciador anuncie o recebimento de avaliação de impacto ambiental de projetos e fixe, em edital, prazo para o requerimento de audiência pública. Havendo solicitação, o órgão licenciador deve proceder à efetiva convocação do interessado, com divulgação na imprensa local (THOMÉ; RIBEIRO, 2016, p. 84, tradução nossa) ${ }^{3}$.

Constata-se que a participação popular disposta no art. 225 da CF/88, destinada à conservação e preservação do meio ambiente equilibrado à sadia qualidade de vida, não está devidamente implementada no processo de AIA no Brasil, pois o acesso da população é limitado ao RIMA no final do procedimento em uma única audiência pública, quando muitas vezes a decisão já

\footnotetext{
3 “The Brazilian legal order is timid when welcoming information and participation instruments related to the environment impact assessment. At a federal level, CONAMA Resolution 09/87 establishes that the permitting environmental agency announces receipt of Environmental Impact Assessments and sets the timeframe for a public hearing to be requested on a public notice. In case a hearing is necessary, the permitting agency has to effectively call the interested parties through the local press.”
} 
está tomada. Niebuhr esclarece que "O que é mais importante, entretanto, é perceber que o pressuposto da cooperação atinente aos afetados vai muito além da participação em audiências públicas” (NIEBUHR, 2014, p. 209).

O Estado Democrático de Direito não pode conviver com essa limitação a um de seus princípios basilares. A democracia participativa está até o presente momento na esfera da utopia, pois não está devidamente consagrada no âmbito da Avaliação de Impacto Ambiental. Conforme propõem Ferreira, Cunha, Rodrigues e Sinesi, "Para que as audiências públicas ambientais se tornem verdadeiros palcos democráticos, os princípios da informação, da educação ambiental e, por consequência, o princípio da participação são cruciais” (FERREIRA et al., 2016, p. 88).

Portanto, conforme todo o exposto, até o momento é possível asseverar que as audiências públicas, como uma espécie de participação popular, não vêm cumprindo com sua missão primordial, que é a de permitir a concreta manifestação da população sobre aqueles empreendimentos, obras ou atividades potencialmente causadores de significativa degradação ambiental.

Atento às críticas apontadas, e às necessidades de um novo paradigma de oportunização de espaços adequados à participação popular na defesa do meio ambiente no âmbito da AIA, traçaremos uma análise evolutiva dedicada a evidenciar novos espaços e novas fases que podem ensejar numa concreta participação popular, no introito de consubstanciar a democracia participativa.

\section{DA NECESSIDADE DE OPORTUNIZAÇÃO DE NOVOS ESPAÇOS PARA A CONCRETIZAÇÃO DA PARTICIPAÇÃO POPULAR NA AIA}

Conforme dito alhures, o processo de avaliação de impacto ambiental se desenvolve basicamente em sete etapas sequenciais. Vejamos novamente: 1) proposta, 2) triagem, 3) escopo, 4) estudos, 5) análise, 6) decisão e 7) acompanhamento. Segundo Fonseca é possível identificar uma oitava etapa: “Diversos autores, com razão, assinalam a existência de uma oitava etapa que permeia (ou deveria permear) todas as sete etapas básicas: participação pública” (FONSECA, 2015, p. 30). Esse parece ser o objeto central do presente estudo, de modo que se trata da assertiva que mais se aproxima do ideal de concretização da democracia participativa em matéria ambiental.

É inaceitável que no ordenamento jurídico vigente a oportunidade de participação popular, no processo de avaliação de impacto ambiental, seja concebida apenas na audiência pública ao final da concretização dos estudos. A democracia participativa assegurada constitucionalmente como pilar de sustentação do Estado Democrático de Direito requer uma participação mais efetiva da população, mais próxima da realidade e das situações concretas dos empreendimentos. Do contrário não haverá 
a concreta participação popular, “[...] haverá, então, mero artifício para legitimação popular da decisão, desde o início tida como certa e inafastável” (MIRRA, 2011, p. 156-157).

A participação popular deve ser oportunizada em todas as etapas do processo de avaliação de impacto ambiental, de modo que a população possa se manifestar adequadamente desde o início do projeto e até a sua efetiva concretização. E, ainda mais, a população tem o direito-dever de manter o acompanhamento do projeto durante seu regular funcionamento, com o fito de fiscalizar o concreto respeito ao projeto fixado no escopo. Como bem salienta Antônio Inagê,

\footnotetext{
Apesar de óbvio, não parece demais salientar que, sendo o meio ambiente um patrimônio comum, de uso de todos, a forma de utilização dos recursos ambientais deve ser a mais democrática possível. Essa forma de utilizar-se tais recursos, estabelecendo preferências em prol do bem comum é uma forma de exercício da arte da política, que deve estar presente em todas as decisões públicas (OLIVEIRA, 2005, p. 485).
}

Não se está aqui a questionar a importância que a audiência pública (espécie do gênero participação popular) representa na avaliação de impacto ambiental. Não se pretende afastar a existência da audiência pública. Ao contrário, o que está sendo defendido é que sejam oportunizados novos momentos para a manifestação popular, pois a realização da audiência pública ao final do procedimento (quando muitas vezes uma decisão já foi tomada) representa uma democracia falaciosa e limitada.

Ante a magnitude dos estudos ambientais e seus consequentes impactos, a realização de uma audiência pública ao final do processo coloca em xeque muitos interesses ambientais que, pela falta de tempo, nem sequer serão discutidos. Conforme preceitua a doutrina, “O tempo concedido aos participantes da audiência pública constitui um dos entraves ao sucesso dessa reunião. Têm-se, na maioria das vezes, um grande número de participantes para um tempo reduzido de participação [...]” (FERREIRA et al., 2016, p. 95).

Para aclarar a proposta apresentada, uma incursão pelas etapas da AIA, citadas anteriormente, se faz necessária. O início dos trabalhos se efetiva com uma proposta, formal e documentada, das atividades que se pretende implantar. Aqui estão presentes todos os detalhes a serem analisados, como, por exemplo, localização, empresa executora, o porte do empreendimento, equipamentos a serem utilizados e as plantas do empreendimento. Na visão de Fonseca, “A apresentação de uma 'boa' proposta, ou seja, de uma proposta clara, objetiva e com riqueza de detalhes sobre o projeto, é fundamental para a formalização do processo” (FONSECA, 2015, p. 31).

Veja-se que, a título de democracia participativa, a população já deveria, na apresentação da proposta, ter um espaço aberto para que pudesse verificar o que está sendo proposto pelo empreendedor, com fito de verificar quais são os impactos ambientais que estão sendo considerados 
pelo proponente. Trata-se do primeiro passo para o desenvolvimento do princípio da informação e da participação popular.

Na análise de Gomes e Ferreira, [...] “uma verdadeira mudança de paradigma se dará em razão do amplo acesso democrático nos debates sobre sustentabilidade e meio ambiente, em uma lógica conexa entre proteger, preservar e desenvolver” (GOMES; FERREIRA, 2017, p. 100).

A triagem é a segunda etapa do procedimento. Aqui serão selecionados quais empreendimentos podem vir a causar significativo impacto ambiental. Na visão de Sánchez, "Tratase de selecionar, dentre as inúmeras ações humanas, aquelas que tenham um potencial de causar alterações ambientais significativas” (SÁNCHEZ, 2008, p. 98).

Se a participação popular deve ser oportunizada com o objetivo de conservar e proteger o meio ambiente, essa participação deve ser oportunizada também na triagem, haja vista que nesse momento a comunidade poderá levantar e apontar quais empreendimentos, em sua visão, poderão causar impacto ambiental significativo.

Sobre a oportunidade de manifestação popular na triagem, Fonseca ensina que "A participação do público na triagem, através da emissão de opinião sobre o enquadramento da proposta, pode auxiliar o órgão competente a melhor compreender os potenciais efeitos da proposta” (FONSECA, 2015, p. 32).

A próxima etapa é exatamente o escopo. Se na etapa de triagem observou-se necessária a realização de estudo de impacto ambiental, a de escopo será responsável por tratar da profundidade e da dimensão que deverão ser observadas nesses estudos. Aqui se dá a formação do Termo de Referência (TR). Nas palavras de Sánchez, “Nos casos em que se mostra necessária a realização do EIA, antes de iniciá-lo é preciso estabelecer seu escopo, ou seja, a abrangência e a profundidade dos estudos a serem feitos” (SÁNCHEZ, 2008, p. 98). Nessa etapa, também é possível afirmar a possibilidade da participação popular, pois a comunidade pode contribuir de forma a orientar e identificar questões relevantes que deverão ser avaliadas: "Na etapa de escopo também é importante a consulta ao público, uma vez que este pode ajudar a autoridade competente identificar questões importantes para serem avaliadas” (FONSECA, 2015, p. 32).

No nível federal, é facultado ao empreendedor apresentar proposta de TR para análise e revisões por parte do Instituto Brasileiro de Meio Ambiente e dos Recursos Naturais Renováveis Ibama. A participação popular nesse processo seria de grande valia.

A etapa central é a elaboração dos estudos. Nessa etapa serão cumpridas e realizadas as determinações de estudos ambientais que restaram evidenciados no Termo de Referência. Geralmente é a etapa mais cara, mais morosa e mais complexa de todo o processo, justamente pelo fato de 
evidenciar de maneira concreta quais são os impactos negativos do projeto e quais são as possibilidades de mitigá-los. Luis Enrique Sánchez identifica que

Essa é a atividade central do processo de avaliação de impacto ambiental, a que normalmente consome mais tempo e recursos e estabelece as bases para a análise da viabilidade ambiental do empreendimento. O estudo deve ser preparado por uma equipe composta de profissionais de diferentes áreas, visando determinar a extensão e a intensidade dos impactos ambientais que poderá causar e, se necessário, propor modificações no projeto, de forma a reduzir ou, se possível, eliminar os impactos negativos. Como os relatórios que descrevem os resultados desses estudos costumam ser bastante técnicos, é usual preparar um resumo escrito em linguagem simplificada e destinado a comunicar as principais características do empreendimento e seus impactos a todos os interessados (SÁNCHEZ, 2008, p. 99).

Aqui é o momento adequado para a ocorrência das consultas públicas ou audiências públicas (espécies de participação popular), contudo, para que as audiências públicas sejam realizadas de forma concreta é preciso que a população já tenha conhecimento do projeto desde o início, pois desse modo estará apta a efetuar consultas pontuais que certamente irão acrescentar legitimidade ao projeto e aos estudos naquilo que importa para o momento - propagar a proteção do meio ambiente.

Na concepção de permear a participação popular por todo o processo de avaliação de impacto ambiental, a realização da audiência pública passaria de mera formalidade legal para o centro da discussão do projeto. Imagine-se o quanto se agregaria à discussão do projeto na audiência pública se desde o início a comunidade já tivesse acompanhado seu desenvolvimento. É importante perceber o quanto as discussões seriam próprias e singulares. A participação das partes envolvidas durante toda a fase da avaliação de impacto poderia gerar significativo avanço epistemológico. A soma de valores, de conclusões e de experiências propiciaria maior legitimidade ambiental ao projeto.

A próxima etapa é a análise, na qual os estudos são direcionados a uma terceira parte. No Brasil as análises dos estudos ambientais geralmente são realizadas por gestores e analistas dos órgãos licenciadores (FONSECA, 2015).

A etapa seguinte é a decisão, pelo órgão ambiental de forma colegiada ou por uma pessoa dotada de grande responsabilidade, um diretor ou presidente, mediante a discussão dos pareces técnicos e jurídicos. A decisão pode ser: pelo indeferimento da proposta; pelo indeferimento da proposta e o seu direcionamento para ajustes nos estudos; pelo deferimento da proposta com condicionantes; ou pelo deferimento da proposta sem condicionantes (SÁNCHEZ, 2008).

Nessa etapa a participação popular poderia, inclusive, subsidiar e influenciar, política e tecnicamente, a tomada de decisão. O intuito seria exatamente permitir maiores pressões populares pelo incentivo ou não à aprovação do projeto, segundo todas as variáreis de proteção ambiental analisadas. Conforme aponta Milaré, 
[...] é no momento da elaboração e, principalmente da discussão do EIA e seu RIMA, normalmente em audiências públicas, que a coletividade e as entidades ambientalistas podem finalmente influir na elaboração e, sobretudo, na forma de execução de planos e atividades que repercutem sobre o meio ambiente (MILARÉ, 2011, p. 105).

A última etapa é aquela do acompanhamento, na qual o proponente e a autoridade têm o dever e a obrigação de fiscalizar e acompanhar se a execução das atividades está respeitando a proposta e os estudos a ela relacionados. Nessa etapa, que geralmente dura por tempo indeterminado, deverá ocorrer a concreta fiscalização, a supervisão e/ou auditoria das atividades que estão sendo desenvolvidas. Trata-se de uma verificação direta e um monitoramento das condições do solo, do ar, da água e da biodiversidade, ou seja, da qualidade ambiental como um todo.

Aqui, é possível considerar que a participação popular é indispensável, haja vista que é a comunidade quem está diariamente e diretamente absorvendo os efeitos do empreendimento. “A população afetada, diferentemente dos fiscais, tende a morar nas proximidades dos projetos, uma situação que facilita a identificação dos efeitos socioambientais” (FONSECA, 2015, p. 36).

A participação popular é importante para acompanhar a efetivação do que foi previsto, pois “Os estudos ambientais apresentam apenas 'previsões'. Na etapa de acompanhamento, cabe à população afetada e às autoridades competentes cobrar dos proponentes controles eficientes sobre os efeitos 'reais' do projeto” (FONSECA, 2015, p. 36).

Permear a participação popular por entre todas as etapas do processo de AIA pode evidenciar uma pretensão utópica, contudo, é bom lembrar que até o ano de 1986 não se falava em nenhum tipo de participação popular na avaliação de impacto e hoje já contamos com as audiências públicas implementadas nos termos das Resoluções Conama 01/86 e 09/87.

Portanto, discutir é preciso, estudar é necessário e avançar é imprescindível. Os rumos para a propagação da proteção ao meio ambiente equilibrado à sadia qualidade de vida dependem do avanço epistemológico da efetiva democracia participativa. Conforme revelam Thomé e Ribeiro:

Além da audiência pública, existem outras técnicas que viabilizam a participação de interessados na avaliação de impactos ambientais: apresentações na fase de planejamento, elaboração participativa de termos de referência, sessões informais para informação pública, oficinas relativas ao projeto, seminários, visitas de campo, material de divulgação sobre o projeto e suas implicações no meio ambiente, definição de medidas mitigadoras e compensatórias, entre outras. (THOMÉ; RIBEIRO, 2016, p. 86, tradução nossa) ${ }^{4}$.

\footnotetext{
4 "Besides the public hearing, there are other techniques that enable the participation of interested parties in the environmental impact assessment: presentations during the planning phase, participative preparation of reference terms, informal sessions for public information, workshops regarding the project, seminars, field visits, material about the project and its consequences for the environment, definition of mitigating and compensating measures, among others.”
} 
O ideal da democracia participativa é premissa inarredável no Estado Democrático de Direito, principalmente no que tange à proteção do meio ambiente equilibrado à sadia qualidade de vida, pois no preceito de ordem constitucional a população tem o dever e ao mesmo tempo o direito de participar da proteção ambiental, de modo a conservá-lo para as presentes e futuras gerações. Nesse mesmo viés, na tentativa de oferecer verdadeira contribuição ao cenário nacional, uma incursão no modelo de participação popular adotado nos estados norte-americanos de Oklahoma e Kansas, na bacia do rio Arkansas, será necessária, o que faremos detalhadamente no tópico seguinte.

\subsection{DO MODELO DE PARTICIPAÇÃO ADOTADO NA BACIA DO RIO ARKANSAS NOS ESTADOS UNIDOS}

O rio Arkansas, afluente do rio Mississipi (EUA), é um dos principais sistemas fluviais do oeste americano, região onde a água, ou a falta dela, nos estados do Kansas e de Oklahoma tem sido uma das grandes preocupações da população e consequentemente da própria administração púbica. A implantação de projetos de significativo impacto ambiental - geração de energia, irrigação e abastecimento para o desenvolvimento urbano nesses estados - gera conflitos, inclusive interestaduais, sobre os direitos da água.

Segundo a Constituição norte-americana, os estados, com o consentimento do Congresso (Cláusula Compacta) $^{5}$, podem resolver problemas em comum, como os de direitos de água, usando a negociação em vez de processos judiciais. O acordo firmado entre os estados de Oklahoma e Kansas, para regular o uso da água em quantidade e qualidade, prevê a discussão das partes interessadas em projetos de impacto ambiental (Compacto da Água, 2009) ${ }^{6}$.

Esse acordo, Kansas-Oklahoma Arkansas River Compact, previamente autorizado pelo Congresso em 1955, aprovado pelos dois estados em 1965 e confirmado pelo Congresso em 1966, é administrado pela Comissão do Rio Arkansas de Kansas-Oklahoma, abrangendo os dois estados.

Para Canter (1977), a metodologia utilizada para a ampla participação popular em um desses projetos na bacia do rio Arkansas, envolvendo os estados de Oklahoma e Kansas, foi considerado exemplar, pela amplitude e metodologia utilizada.

Nesse diapasão, para Thomé e Ribeiro, o exemplo citado por Canter foi destacado com o fito de indicar uma alternativa inspiradora para metodologias a serem adotadas no Brasil:

No que atine a exemplo bem-sucedido de participação pública, releva mencionar o programa realizado conjuntamente pelos estados de Oklahoma e Kansas, na bacia do rio Arkansas. Este

\footnotetext{
${ }^{5}$ Compact Clause.

${ }^{6}$ Water Compacts, 2009.
} 
programa consistiu na realização de sete sessões de informação pública e treze oficinas específicas relacionadas ao projeto. Essas vinte reuniões foram realizadas em várias cidades e vilas da bacia. Em apertada síntese, podem ser enumerados os seguintes resultados: a) As vinte reuniões contaram com um total de 1.600 participantes. b) Os participantes não foram apenas os residentes das sedes das reuniões. Mais de quarenta por cento percorreram distâncias superiores a dez milhas, a partir das cidades de encontro. Assim, as pessoas foram atraídas de todas as partes da bacia. c) As perguntas e respostas em cada reunião foram caracterizadas pela participação ativa de muitos participantes. d) Os questionários de opinião sobre vários aspectos do estudo foram recebidos de mais de setenta por cento dos participantes. e) A análise dos resultados do questionário indicou que a maioria dos participantes considerou as reuniões muito produtivas (THOMÉ; RIBEIRO, 2016, p. 86, tradução nossa $)^{7}$.

Conforme o modelo citado, a plena participação popular incluiu como primeiro passo a socialização da informação, fundamental para reduzir a assimetria do conhecimento do projeto e seus impactos, entre os participantes. Destacam-se, além das sessões públicas, a realização de oficinas e aplicação de questionários que permitirão maior interatividade entre as partes. Os resultados relatados apresentaram ampla participação, inclusive de várias partes da bacia, com avaliações positivas por parte dos participantes. Nesse mesmo sentido, Thomé e Ribeiro, prosseguem:

Um dos aspectos que foi considerado a chave para o sucesso do referido programa norteamericano foi a parceria instaurada entre empreendedores e patrocinadores locais nos esforços para a promoção e realização dessas vinte reuniões. Cada reunião consistiu em uma apresentação de slides, seguida de sessão informal com questionamentos e respostas, quando foram envidados todos os esforços para fornecer as informações de interesse para o público. Além disso, foi entregue a cada participante material informativo sobre o projeto, seus impactos sobre o ambiente, e as respectivas medidas mitigadoras e compensatórias.

O programa de participação pública executado na bacia do rio Arkansas empregou diversas modalidades de técnicas de participação popular, viabilizando, em observância ao postulado do princípio democrático em matéria ambiental, a efetiva participação de representantes da sociedade civil. O Poder Público, nesse caso, promoveu a utilização de técnicas hábeis a possibilitar ativa participação pública antes de decidir em matéria ambiental, exemplo que deve ser seguido por outros programas de participação popular (THOMÉ; RIBEIRO, 2016, p. 86-87, tradução nossa) ${ }^{8}$.

\footnotetext{
7 "To mention a successful example of public participation, it is worth talking about the joint program between the states of Oklahoma and Kansas, in the basin of the Arkansas river. That program consisted in seven public information sessions and thirteen specific workshops related to the project. Those twenty meetings were held in different cities and villages at the basin. The following results can be listed: a) The twenty meetings counted on a total of 1,600 participants. b) The participants were not only the people who lived in the places where the meetings were held. Over forty per cent of them traveled over ten miles to get there. Thus, people were attracted from all over the basin. c) Questions and answers during each meeting counted on the active participation of many participants. d) Opinion questionnaires on different aspects of the study were received from over seventy per cent of the participants. e) The analysis of questionnaire results showed that most of the participants thought that the meetings were very productive."

8 "One of the aspects that was considered the key to the success of the aforementioned North American program was the partnership between entrepreneurs and local sponsors in the efforts to promote and hold these twenty meetings. Each meeting consisted of a slide show followed by an informal session with questions and answers when every effort was made to provide the information of interest to the public. In addition, informative material about the project, its impacts on the environment, and the respective mitigating and compensatory measures were given to each participant.

The public participation program carried out in the Arkansas River Basin employed a variety of techniques of popular participation, making effective the participation of representatives of civil society, in compliance with the principle of democratic principles in environmental matters. The Public Power, in this case, promoted the use of skillful techniques
} 
Nesse exemplo relatado por Canter (1977) e referenciado como alternativa metodológica por Thomé e Ribeiro (2016), seriam necessários, para inspirar a efetiva participação popular no processo de tomada de decisão em Avaliações de Impactos Ambientais, avanços consideráveis nas metodologias que vêm sendo utilizadas no Brasil, pois o modelo de participação popular no País, restrito às audiências públicas, está baseado em manifestações estáticas, sem utilização de qualquer técnica de mediação, resultando no máximo em algumas compensações, quando não em barganhas oportunistas.

Para tanto, para que o ideal de participação popular (democracia participativa) em matéria ambiental na AIA seja concretamente oportunizado no Brasil, nos termos do ocorrido na bacia do rio Arkansas nos Estados Unidos da América, seria necessário uma mudança de pensamento e de paradigma, que tenha o condão de estabelecer uma espécie de “compact clause”, em que empreendedores e sociedade, com aprovação dos órgãos ambientais, pudessem resolver problemas comuns, como o direito à utilização de recursos naturais, respeitando os parâmetros legais de qualidade ambiental e utilizando-se a negociação, em vez de processos judiciais.

Além do mais, julga-se necessário após a negociação seja previsto o acompanhamento, pelas partes, do acordo firmado, que também deveria prever sanções por descumprimento, com execução direta, como nos acordos extrajudiciais.

\subsection{DO PRINCÍPIO DA INFORMAÇÃO}

Quando se fala em mudança de paradigma, dois princípios constitucionais precisam ser observados e corretamente desenvolvidos para consubstanciar o princípio da democracia participativa em matéria ambiental, quais sejam, o princípio da informação e o princípio da educação ambiental. Esses dois princípios são de fundamental importância para que a plena participação popular ocorra em seu nível mais elevado. Conforme assevera a doutrina, “O que pode trazer uma reorganização de poder e autoridade são a informação e educação ambiental somada às políticas ambientais eficientes com acesso à participação e transparência na gestão dos problemas ambientais” (GOMES; TEIXEIRA, 2017, p. 142).

O princípio da informação está previsto no art. 225, inciso IV, da CF/88, determinando-se expressamente que compete ao Poder Público dar publicidade ao Estudo de Impacto Ambiental. De

to enable active public participation before deciding on environmental issues, an example that should be followed by other popular participation programs.” 
modo que é um direito inerente a toda a população interessada ter acesso aos Estudos de Impacto Ambiental para que possam fomentar futuras discussões sobre o projeto. O princípio da informação, portanto, é pilar de sustentação do princípio da democracia participativa, haja vista que apenas aquelas pessoas devidamente informadas terão condições de realizar debates construtivos e pertinentes sobre o projeto.

Assim, Paulo Affonso Leme Machado assevera que “A qualidade e a quantidade de informação irão traduzir o tipo e a intensidade da participação na vida social e política. Quem estiver mal informado nem por isso estará impedido de participar, mas a qualidade de sua participação será prejudicada” (MACHADO, 2018, p. 34).

Por isso o princípio da informação se tona tão importante e indispensável no cenário do meio ambiente e, principalmente, nos Estudos de Impacto Ambiental, pois a população chamada a participar, discutir e intervir em todas as fases do processo precisa ter pleno conhecimento das atividades que poderão ser nocivas ou não ao meio ambiente, sendo certo que não é possível expressar manifestação ou opinião de algo que não se conhece. Participação sem a devida informação é mero sofisma e falácia, que não eleva o princípio da democracia participativa; ao contrário, coloca-o em condição utópica.

Não pode ser esse o retrato da democracia participativa no Estado Democrático de Direito. A plena participação pressupõe a existência de sujeitos que estejam aptos a produzir e a estimular debates sinceros e honestos em prol de uma deliberação que se preocupe em promover a verdadeira justiça socioambiental. O debate pelo debate em nada potencializa a democracia; ao contrário, acaba por imobilizá-la, de modo que o debate precisa ser enriquecido com preposições e intervenções inerentes ao tema discutido no projeto. O cidadão precisa conhecer o conteúdo da discussão para formar sua opinião e emitir suas próprias considerações, sendo certo que isso só é possível quando o cidadão está devidamente informado sobre o assunto.

Uma parte da doutrina vem consagrando o princípio da informação como um direito fundamental de quarta dimensão, em razão da sua real importância no cenário da promoção da tutela ambiental, e é por isso que alguns autores especializam um “direito à informação ambiental”, qualificado como direito de quarta geração (SAMPAIO, 2003, p. 77). Nessa mesma perspectiva é a contribuição de Tiago Fensterseifer, segundo o qual “[...] o direito à informação constitui-se de direito fundamental de quarta dimensão, assim como o direito à democracia e ao pluralismo, já que da realização desses direitos depende a concretização da sociedade aberta ao futuro [...]” (FENSTERSEIFER, 2008, p. 126). 
Ainda assim, cabe sustentar que a informação apta a produzir efeitos em matéria de participação ambiental evoca quatro características centrais, quais sejam: a informação precisa deter veracidade, amplitude, tempestividade e acessibilidade. Dados falsos, incompletos, intempestivos e inacessíveis não perfazem as determinações do princípio da informação; pelo contrário, tornam a informação ineficiente e ineficaz. Nesse mesmo diapasão Machado atesta que, “assim, a informação deve ser veraz, contínua, tempestiva e completa. Destaco algumas características essenciais à informação ambiental: sua tecnicidade, compreensibilidade e rapidez” (MACHADO, 2011, p. 911).

Não há que se negar, portanto, a importância que deve ser atribuída ao princípio da informação em matéria ambiental, haja vista que ele aparece como direito fundamental de quarta dimensão comprometido com a democracia participativa, responsável por munir a população com as ferramentas necessárias para o debate ambiental.

Igual importância merece ser dada ao princípio da educação ambiental, pois somente uma sociedade devidamente informada e adequadamente educada sobre os assuntos ambientais poderá exercitar e promover a plena democracia participativa.

\subsection{DO PRINCÍPIO DA EDUCAÇÃO AMBIENTAL}

O princípio da educação ambiental está devidamente insculpido no art. 225, § $1^{\circ}$, inciso VI, da CF/88, atribuindo-se ao Poder Público o dever de promover a educação ambiental em todos os níveis de ensino, de modo a propalar verdadeira e concreta conscientização ambiental. Assim, cabe ao Poder Público propiciar o acesso à educação ambiental em todas as esferas, classes e camadas sociais. Segundo mandamento constitucional, a população deve estar educada ambientalmente.

Ao alçar o direito ao meio ambiente equilibrado à sadia qualidade de vida ao status de norma de direito fundamental, a Constituição elevou a esfera de preocupação e também de alcance do tema meio ambiente, de modo que restou à incumbência de toda a população e também do Poder Público protegê-lo e preservá-lo em favor das presentes e futuras gerações. Nada mais coerente, portanto, que aqueles legitimados à defesa do meio ambiente sejam educados à tratativa da matéria. Nessa mesma lógica a doutrina afirma que "Uma das maneiras de todas as pessoas adquirirem essa consciência, conhecimentos e habilidades necessárias à melhoria de sua qualidade de vida se dá por meio da Educação Ambiental” (MANSUR LINHARES; PIEMONTE, 2011, p. 108).

Nesse passo, no objetivo de regulamentar o texto constitucional e efetivar a educação ambiental no cenário nacional, foi editada a Lei 9.795/99, que instituiu a Política Nacional de Educação Ambiental. A edição da Lei da Política Nacional de Educação Ambiental representa 
verdadeiro avanço no cenário nacional, haja vista traçar as diretrizes e bases fundamentais para o desenvolvimento de uma educação ambiental concreta e eficiente.

A nosso ver, pelo menos naquilo que importa ao presente ensaio, merecem destaque alguns dispositivos da Lei 9.795/99. O art. $1^{\circ}$ tratou de apontar uma definição legal para o tema educação ambiental, entendendo-o como sendo os processos pelos quais o indivíduo e a coletividade desenvolvem valores sociais, conhecimentos, habilidades, atitudes e competências voltadas para a conservação do meio ambiente. Outro dispositivo que merece destaque é o art. $4^{\circ}$, inciso I, da Lei 9.795/99: “Art. 4o São princípios básicos da educação ambiental: I - o enfoque humanista, holístico, democrático e participativo” (BRASIL, 1999).

Com efeito, a própria Lei destaca que um de seus princípios básicos é exatamente o exercício da democracia participativa, ou seja, o cidadão e a comunidade devem ser apropriadamente educados em temáticas ambientais, para professar a defesa do meio ambiente equilibrado à sadia qualidade de vida pela via democrática. Portanto, a educação ambiental deve permear toda a sociedade, de modo a formar cidadãos e cidadãs ambientalmente instruídos a debater e a se insurgir contra aquelas decisões maléficas e prejudiciais ao bem ambiental. Nessa mesma perspectiva, José Rubens Morato Leite leciona que “[...] a democracia ambiental participativa e solidária pressupõe, ainda, um cidadão informado e uma coletividade que detenha como componente indispensável a educação ambiental” (LEITE, 2011, p. 573).

Merece destaque ainda o art. $9^{\circ}$ da Lei 9.795/99, o qual destaca que a educação ambiental deve permear as grades curriculares das escolas públicas e privadas, da educação básica (educação infantil, ensino fundamental, ensino médio), da educação superior, da educação especial, da educação profissional e da educação de jovens e adultos. Nessa vertente, é possível considerar que o interesse do legislador é justamente determinar que a matéria ambiental seja estudada por todas as pessoas, em todas as idades e em todas as classes sociais. Tal dispositivo permite que crianças, jovens, adultos e idosos, favorecidos ou desfavorecidos economicamente, tenham contato direto com as demandas ambientais.

Assim, mediante o enfoque dos princípios da informação e da educação ambiental, será possível o desenvolvimento e a implementação da democracia participativa ambiental. Portanto, há que ser evoluído o sistema brasileiro de avaliação de impacto ambiental, de modo a permitir e possibilitar a efetiva democracia participativa em matéria ambiental, com vistas a propagar a efetiva proteção e conservação do meio ambiente ecologicamente equilibrado à sadia qualidade de vida para as presentes e futuras gerações. Visto que, a um só tempo, a Constituição Federal de 1988 elevou o 
meio ambiente equilibrado e a participação popular em prol da sua defesa ao status de normas de direito fundamental.

\section{CONSIDERAÇÕES FINAIS}

Restou evidenciado que no âmbito do Estado Democrático de Direito o princípio da participação popular deve ser entendido como princípio da democracia participativa, e daí se extrai que se trata de um princípio fundamental inafastável e de aplicação incondicionada, visto que no Estado Democrático de Direito todo o poder emana do povo.

No que tange à matéria ambiental, o princípio da participação popular é premissa inarredável que se fundamenta na própria proteção ao direito fundamental do meio ambiente ecologicamente equilibrado, ao qual a coletividade tem o direito-dever de participar da sua proteção e conservação.

Demonstrou-se que o direito ao meio ambiente ecologicamente equilibrado à sadia qualidade de vida insculpido no art. 225 da CF/88, constitui-se em direito fundamental de terceira geração que se confunde com o próprio direito à vida e como tal merece aplicação imediata no Estado Democrático de Direito, justamente por meio da participação popular efetiva.

Observou-se os aspectos do método de avaliação de impacto ambiental, por meio de uma incursão na Constituição Federal, na legislação federal e nas resoluções do Conama que norteiam a aplicação da matéria. Verificou-se que os espaços oportunizados à participação popular na legislação ambiental, sobretudo nas Resoluções Conama 01/86 e 09/87 são limitados à audiência pública.

A oportunidade de manifestação popular apenas na audiência pública, quando os estudos já foram realizados e quando, em muitos casos a decisão sobre o projeto já foi tomada, coloca em xeque a existência da concreta democracia participativa em matéria ambiental. Para superar essa limitação da participação popular, foi proposta uma nova metodologia que permite a participação popular em todas as etapas do processo de avaliação de impacto ambiental.

Verificou-se que o modelo que permeia a participação popular em todas as etapas da AIA cumpre com os objetivos do Estado Democrático de Direito, que se fundamenta na participação da coletividade como um direito-dever de proteger e conservar o meio ambiente ecologicamente equilibrado à sadia qualidade de vida, direito fundamental. Foi observado que na bacia do rio Arkansas, nos Estados Unidos da América, o modelo de participação popular em todas as etapas do processo de avaliação de impacto ambiental foi um verdadeiro sucesso, tendo a população participado efetivamente na tomada de decisões dos projetos ambientais. 
Para que o ideal da participação popular em matéria ambiental seja devidamente implementado, um avanço epistemológico e social precisa ser pensando e desenvolvido, por meio da difusão do princípio da informação e da educação ambiental, para que a participação popular seja oportunizada ao máximo como efetivo exercício de cidadania ambiental.

Ao final, foi observado que uma evolução do sistema brasileiro de avaliação de impacto ambiental deve ser consubstanciada, de modo a permitir e possibilitar a efetiva democracia participativa em matéria ambiental, com vistas a propagar a efetiva proteção e conservação do meio ambiente ecologicamente equilibrado à sadia qualidade de vida em prol das presentes e futuras gerações. Pois, a um só tempo, a Constituição Federal de 1988 elevou, ao nível de normas de direito fundamental, o meio ambiente equilibrado e a participação popular em prol da sua defesa e proteção.

\section{REFERÊNCIAS}

AMADO, Frederico Augusto Di Trindade. Direito ambiental esquematizado. 7. ed. Rio de Janeiro: Forense; São Paulo: Método, 2016.

BIM, Eduardo Fortunato. Avaliação ambiental estratégica (AAE), licenciamento ambiental e autocontenção judicial. Revista brasileira de direito constitucional aplicado, São Gotardo, v. 2, n. 1, p. 141-180, jan./jun. 2015. Disponível em: <https://goo.gl/CV79R9>. Acesso em: 19 maio 2018.

BIM, Eduardo Fortunato; FARIAS, Talden. Competência ambiental legislativa e administrativa. Revista de informação legislativa, Brasília, a. 52, n. 208, p. 203-245, out./dez. 2015. Disponível em: <https://goo.gl/bMk8zs>. Acesso em: 19 maio 2018.

BONAVIDES, Paulo. Teoria constitucional da democracia participativa. 2. ed. São Paulo: Malheiros, 2003. 392 p.

BRASIL. Lei n ${ }^{0}$ 9.795, de 27 de abril de 1999. Dispõe sobre a educação ambiental, institui a Política Nacional de Educação Ambiental e dá outras providências. Diário Oficial da União, Brasília, 27 abr. 1999. Disponível em: <https://goo.gl/v7NypG>. Acesso em: 19 maio 2018.

BRASIL. Conselho Nacional do Meio Ambiente. Resolução Conama no 001, de 23 de janeiro de 1986. Dispõe sobre critérios básicos e diretrizes gerais para a avaliação de impacto ambiental. Diário Oficial da União, Brasília, 17 fev. 1986. Disponível em: <https://goo.gl/r2Zec>. Acesso em: 30 nov. 2017.

BRASIL. Conselho Nacional do Meio Ambiente. Resolução Conama no 009, de 03 de dezembro de 1987. Dispõe sobre a realização de Audiências Públicas no processo de licenciamento ambiental. Diário Oficial da União, Brasília, 05 jul. 1990. Disponível em: <https://goo.gl/jZpGE4>. Acesso em: 30 nov. 2017.

BRASIL. Constituição da República Federativa do Brasil 1988. Diário Oficial da União, Brasília, 05 out. 1988. Disponível em: <https://goo.gl/wUgZP>. Acesso em: 30 nov. 2017. 
BRASIL. Lei n 6.938, de 31 de agosto de 1981. Dispõe sobre a Política Nacional do Meio Ambiente, seus fins e mecanismos de formulação e aplicação, e dá outras providências. Diário Oficial da União, Brasília, 02 set. 1981. Disponível em: <https://goo.gl/L1YXP6>. Acesso em: 30 nov. 2017.

BULOS, Uadi Lammêgo. Curso de direito constitucional. 10. ed. São Paulo: Saraiva, 2017. 1.727 p.

CANTER, Larry W. Environmental Impact Assessment. New York, USA: MacGraw-Hill Book Company, 1977.

CONFERÊNCIA DAS NAÇÕES UNIDAS SOBRE MEIO AMBIENTE E DESENVOLVIMENTO - ECO 92. Declaração do Rio sobre Meio Ambiente e Desenvolvimento. 1992. Disponível em: $<$ https://goo.gl/hgFWp>. Acesso em: 30 nov. 2017.

FENSTERSEIFER, Tiago. Direitos fundamentais e proteção do ambiente: a dimensão ecológica da dignidade humana no marco jurídico-constitucional do Estado Socioambiental de Direito. Porto Alegre: Livraria do Advogado, 2008.

FERREIRA, Leandro José; GOMES, Magno Federici. A teoria neoinstitucionalista do processo e a possibilidade de concessão de tutela provisória liminar para a proteção do direito fundamental ao meio ambiente. Revista Argumentum, Marília, v.18, n. 3, p. 625-643, set./dez. 2017. Disponível em: <https://goo.gl/yk91o9>. Acesso em: 18 maio 2018.

FERREIRA, Lennon Giovanni Gonçalves et al. Comentários sobre os artigos $7^{\circ}$ a 12 da Conama 01/86. In: RIBEIRO, José Cláudio Junqueira (Coord.). Resolução Conama 01/86 comentada: erros e acertos. Rio de Janeiro: Lumen Juris, 2016. p. 63-105.

FONSECA, Alberto. A avaliação de impacto ambiental e o seu vínculo com o licenciamento ambiental. In: RIBEIRO, José Cláudio Junqueira (Coord.). Licenciamento ambiental: herói, vilão ou vítima? Belo Horizonte: Arraes, 2015. p. 27-41.

GOMES, Magno Federici; FERREIRA, Leandro José. A dimensão jurídico-política da sustentabilidade e o direito fundamental à razoável duração do procedimento. Revista do Direito, Santa Cruz do Sul, v.2, n. 52, p. 93-111, out. 2017. Disponível em: <https://goo.gl/op1LCF>. Acesso em: 19 mar. 2018.

GOMES, Magno Federici; TEIXEIRA, Angélica Cristiny Ezequiel de Avelar. Da participação social nos licenciamentos ambientais: para além da audiência pública. RVMD, Brasília, v. 11, nº 1, p. 128146, jan./jun. 2017. Disponível em: <https://goo.gl/LLNKiK>. Acesso em: 30 nov. 2017.

LEITE, José Rubens Morato. Ação popular: um exercício da cidadania ambiental? In: MILARÉ, Édis; MACHADO, Paulo Affonso Leme (Coord.). Direito ambiental: Tutela do meio ambiente. São Paulo: Revista dos Tribunais, 2011. p. 571-590.

MACHADO, Paulo Affonso Leme. Direito à informação e meio ambiente. 2. ed. São Paulo: Malheiros, 2018. 
MACHADO, Paulo Affonso Leme. Princípios do direito ambiental e tutela penal. In: MILARÉ, Édis; MACHADO, Paulo Affonso Leme (Coord.). Direito ambiental: Tutela do meio ambiente. São Paulo: Revista dos Tribunais, 2011. p. 901-917.

MANSUR LINHARES, Mônica Tereza; PIEMONTE, Márcia Nogueira. Meio ambiente e educação ambiental: à luz do princípio da dignidade da pessoa humana. Veredas do direito, Belo Horizonte, v. 7, n. 13/14, p. 101-124, ago. 2011. Disponível em: <https://goo.gl/m6pVDj>. Acesso em: 19 maio 2018.

MILARÉ, Édis. Legislação ambiental e participação comunitária. In: MILARÉ, Édis; MACHADO, Paulo Affonso Leme (Coord.). Direito ambiental: Tutela do meio ambiente. São Paulo: Revista dos Tribunais, 2011. p. 91-111.

MIRRA, Álvaro Luiz Valery. Participação, processo civil e defesa do meio ambiente. São Paulo: Letras Jurídicas, 2011.

NIEBUHR, Pedro de Menezes. Processo administrativo ambiental. Rio de Janeiro: Lumen Juris, 2014.

OLIVEIRA, Antônio Inagê de Assis. Introdução à legislação ambiental brasileira e licenciamento ambiental. Rio de Janeiro: Lumen Juris, 2005.

ORGANIZAÇÃO DAS NAÇÕES UNIDAS. Acuerdo Regional sobre el Acceso a la Información, la Participación Pública y el Acceso a la Justicia en Asuntos Ambientales en América Latina y el Caribe, adoptado en Escazú (Costa Rica) el 4 de marzo de 2018. Santiago: Naciones Unidas, 2018.

SAMPAIO, Izabel Cristina da Silva. Informação ambiental: a convenção de Aarhus e seu contributo no âmbito da União Européia. Revista do Instituto do Direito Brasileiro, Lisboa, n. 12, p. 14.23314.247, 2013. Disponível em: <https://goo.gl/G2CzyH>. Acesso em: 19 maio 2018.

SAMPAIO, José Adércio Leite. Constituição e meio ambiente na perspectiva do direito constitucional comparado. In: SAMPAIO, José Adércio Leite; WOLD, Chris; NARDY, Afrânio (Coord.). Princípios de direito ambiental na dimensão internacional e comparada. Belo Horizonte: Del Rey, 2003. p. 37-86.

SÁNCHEZ, Luis Enrique. Avaliação de impacto ambiental: conceitos e métodos. São Paulo: Oficina de Textos, 2008.

SARLET, Ingo Wolfgang; FENSTERSEIFER, Tiago. Democracia participativa e participação pública como princípios do Estado socioambiental de direito. In: CLÈVE, Clèmerson Merlin (Coord.). Direito constitucional: processo constitucional: tomo I. São Paulo: Revista dos Tribunais, 2015. p. 709-757.

SILVA, Romeu Faria Thomé. Manual de direito ambiental. 2. ed. Salvador: JusPodivm, 2012.

THOMÉ, Romeu; RIBEIRO, José Cláudio Junqueira. Community participation in the analysis of the environmental impact assessment as a democratic mechanism to insure social-environmental rights. 
Veredas do Direito, Belo Horizonte, v. 13, $\mathrm{n}^{0}$ 25, p. 69-91, jan./abr. 2016. Disponível em: <https://goo.gl/hKYLVq>. Acesso em: 30 nov. 2017.

ZANETI JR., Hermes. A teoria da separação de poderes e o estado democrático constitucional: funções de governo e funções de garantia. In: GRINOVER, Ada Pellegrini; WATANABE, Kazuo (Coord.). $O$ controle jurisdicional de políticas públicas. 2. ed. Rio de Janeiro: Forense, 2013. p. 3372. Dom Helder Câmara - ESDHC, Especialista em Direito Processual pela PUC/MG e Advogado Militante.E-mail: leandrojfadv@gmail.com

José Cláudio Junqueira Ribeiro Doutor em Saneamento, Meio Ambiente e Recursos Hídricos pela UFMG e Professor do Programa de Pós-graduação da ESDHC - Mestrado em Direito Ambiental e Desenvolvimento Sustentável.E-mail: jcjunqueira@yahoo.com 